\title{
Aspek Bahasa sebagai Pembeda antara Kemu'jizatan al-Qur'an dan Bukti-Bukti Kebenarannya
}

\begin{abstract}
Yusuf Baihaqi
E-mail : baihaqi_yusuf@yahoo.com

Fakultas Syari'ah dan Program Pascasarjana IAIN Raden Intan Lampung

Alamat Korepondensi: Jalan Letkol H. Endro Suratmin Sukarame Bandar Lampung 35131

Abstract

There is ambiguity in identifying the aspects of al-Qur'an miracles, that is caused by no clear difference in understanding the aspects of al-Qur'an miracles and the justification. To understand those two aspects, the aspect that makes al-Qur'an as a holy script that have miracles and the aspect that justify that al-Qur'an is from Allah swt, there is an important step so that we will not be entrapped in the ambiguity. In addition, there is a difference among the ulama (Islamic scholars) in formulating the aspects of miracle in al-Qur'an. This is a difference emerging at the early generation of Islamic development. Along the history, the difference is more and more varied. Language aspect is the only aspect that makes al -Qur'an as a holy script having miracle. While the content of al -Qur'an such as the news of ghaib, law completeness, and Allah's miracle spread in the universe has no relationship with the challenge implied to the miracle, instead the miracle in the content of al-Qur'an as part of the proof justifying that alQur'an is from Allah swt.
\end{abstract}

\section{Kata Kunci}

Bahasa, Mu'jizat al-Qur'an, Bukti-Bukti Kebenaran al-Qur'an

\section{Pendahuluan}

Sangat penting bagi kita untuk mengidentifikasi aspek kemukjizatan al-Qur'an yang sesungguhnya, apalagi di era saat ini dengan mudahnya seseorang menjustifikasi sebuah aspek untuk menjadi bagian dari aspek kemukjizatan al-Qur'an. Sebab, kesalahan dan ketidak akuratan dalam mengidentifikasi aspek kemukjizatan al-Qur'an, akan berdampak kontra produktif bagi al-Qur'an itu sendiri.

Tumpang tindih pembahasan seputar aspek kemukjizatan al-Qur'an, sering didapatkan dalam banyak buku yang ditulis beberapa ulama yang menjadikan antara aspek kemukjizatan dan aspek-aspek bukti kebenaran al-Qur'an sebagai satu kesatuan, tidak melihat adanya perbedaan antara keduanya. Aspek bahasa merupakan aspek kemukjizatan al-Qur'an, sebaliknya aspek pemberitaan, hukum dan ilmu pengetahuan merupakan bagian dari aspek-aspek bukti kebenaran al-Qur'an, demikian menurut pemahaman penulis.

Atas dasar itulah dalam tulisan ini, penulis berupaya untuk mengkaji problematika seputar aspek bahasa al-Qur'an dengan terlebih dahulu membahas perbedaan ulama seputar aspek kemukjizatan al-Qur'an, kemudian mengkaji sisisisi kesamaan dan perbedaan antara kemukjizatan dan bukti pembenar, lalu diteruskan dengan mengungkap alasan-alasan kenapa hanya aspek bahasa yang dapat dijadikan sebagai aspek kemukjizatan al-Qur'an. Ini semua penulis lakukan dalam rangka untuk menguatkan pemahaman di atas, mengingat masih banyaknya pemahaman yang menjadikan problematika ini sebagai alasan untuk menyatukan aspek bahasa dengan aspek-aspek kandungan al-Qur'an.

Penulis berharap tulisan ini dapat memberi kontribusi dalam memperluas wawasan dan memahami aspek kemukjizatan al-Qur'an yang berlandaskan argumentasi kuat, sehingga dapat berimplikasi kepada perolehan sebuah pemahaman komprehensif dalam memahami hakekat kemukjizatan al-Qur'an dan bukti-bukti kebenarannya.

\section{Perbedaan Ulama Seputar Aspek Kemu'jizatan al-Qur'an}

Sesungguhnya perbedaan di antara ulama seputar aspek kemukjizatan al-Qur'an baru muncul pasca generasi awal karena fenomena tersebut belum ditemukan pada era sahabat, 
tabi'in bahkan di era tabi' tabi'in. Kemunculannya baru didapatkan pada generasi setelah mereka.

Telah banyak kajian seputar aspek kemukjizatan al-Qur'an yang dihasilkan baik oleh para ulama klasik maupun kontemporer. Penafsiran yang beragam pun didapatkan seputar masalah kemukjizatan. Di antara mereka, ada yang mengatakan bahwa aspek kemukjizatan al-Qur'an hanya terletak pada aspek bayani-nya saja, sebuah istilah yang sering digunakan untuk penisbatan aspek kemukjizatan al-Qur'an dari sisi bahasanya, ada pula yang menambahkan dengan aspek-aspek lain yang berkaitan dengan kandungan dan realitas al-Qur'an, seperti: aspek pemberitaan, aspek ilmu pengetahuan, aspek hukum, aspek psikologi, aspek bilangan, aspek kedokteran, aspek musik, dan masih banyak aspek-aspek lain yang kompleksitas pembahasannya seputar kemukjizatan al-Qur'an di era sekarang ini justru menimbulkan banyak kerancuan.

Dibawah ini, penulis paparkan pendapat dari beberapa ulama terkenal yang dapat menggambarkan perbedaan yang terjadi diantara mereka seputar aspek kemukjizatan al-Qur'an.

Pada abad ketiga hijiriyah, Abu Ishak al-Nazham, seorang ulama yang berhaluan Mu'tazilah, mengatakan "Al-Qur'an memiliki kandungan mukjizat karena Allah swt menghalau kaum kafir untuk menantang al-Qur'an", sebuah teori kemukjizatan yang dikenal dengan teori "sharfah". Kemudian, masih pada abad yang sama, al-Jahizh, murid beliau yang juga berhaluan Mu'tazilah, berupaya membantah pendapat gurunya di atas dengan mengatakan, "Bahwa alQur'an memiliki kandungan mu'jizat dikarenakan aspek bayani-nya tidak dimiliki oleh selainnya" (Abdul Fatah, 2000:83).

Pada abad kelima hijriyyah yang merupakan era keemasan untuk masa lampau bagi tumbuh pesatnya ide dan pemikiran seputar kemukjizatan al-Qur'an, muncul sosok alBaqilani, seorang ulama besar yang kerap dijadikan rujukan oleh para ulama setelahnya. AlBaqilani mengatakan, "Kemukjizatan al-Qur'an terdapat pada tiga aspek. Pertama, kandungan alQur'an seputar pemberitaannya yang bersifat futuristik; kedua, penyebutan al-Qur'an seputar kejadian-kejadian pada masa lampau dan kisahkisah para pendahulu; ketiga, nazhm (puisi \& sajak) al-Qur'an, usluub (style atau gaya) dan balaghah (kefasihan) yang dimilikinya" (AlBaqilani, 1978:12-13).

Pada abad ketujuh hijriyah, muncul sosok Al Qurthubi, pengarang tafsir al-Jaami' ILi Ahkaam
al-Qur'an, yang mengatakan, "Bahwa kemukjizatan al-Qur'an terdapat pada sepuluh aspek. Pertama, nazhm al-Qur'an yang sangat indah, yang berbeda dengan nazhm yang biasa dikenal, baik dalam lisan (percakapan) bangsa Arab maupun bangsa non Arab. Kedua, Usluub alQur'an yang juga berbeda dengan segenap Usluub lain yang dimiliki oleh bahasa Arab. Ketiga, balaghah (kefasihan) al-Qur'an yang tidak mungkin terlahir semacamnya dari seorang makhluk. Keempat, akurasi penempatan dari setiap huruf dan kalimat yang terdapat dalam setiap redaksional al-Qur'an. Kelima, pemberitaan al-Qur'an tentang perkara-perkara yang telah terjadi dari semenjak awal kejadian dunia hingga masa diturunkannya, dari diri Muhammad saw yang seorang buta aksara dan tidak pernah mengecap dunia pendidikan sebelumnya. Keenam, pemenuhan al-Qur'an terhadap janji-janjinya. Ketujuh, pemberitaan alQur'an tentang perkara-perkara ghaib yang terjadi di kemudian hari, yang pengetahuan seputarnya tidak mungkin didapatkan kecuali melalui perantara wahyu. Kedelapan, kandungan ilmu pengetahuan al-Qur'an seputar perkara halal dan haram dan yang berkaitan dengan segenap perkara hukum lainnya, yang menjadi dasar bagi kemaslahatan segenap umat manusia. Kesembilan, keagungan dan kemuliaan hikmah alQur'an yang tidak umum untuk terlahir semacamnya dari seorang manusia. Kesepuluh, kesesuaian dan tidak adanya pertentangan pada setiap kandungan al-Qur'an, baik yang bersifat dhahir (eksternal) maupun batin (internal) (AlQurtubi, 1993:71-73).

Pada abad keempat belas hijriyyah, terjadi satu kebangkitan ilmu pengetahuan yang sangat pesat. Pada abad ini banyak dari kalangan ulama, cendekiawan dan penulis yang membahas seputar kemukjizatan al-Qur'an, bahkan tidak sedikit dari mereka yang menambahkan aspek baru dari aspek-aspek kemukjizatan yang dimiliki al-Qur'an yang lalu menghadirkan sebuah analisis dan kajian yang sangat berguna dan bermakna. Atas dasar itu, sangat tepat kalau abad ini dikatakan sebagai abad keemasan kedua bagi tumbuh pesatnya ide dan pemikiran seputar kemukjizatan al-Qur'an.

Secara garis besar, mereka yang berbicara seputar aspek kemukjizatan al-Qur'an pada abad keempat belas hijriyyah ini dapat digolongankan menjadi dua golongan :

\section{Golongan pertama, penggagas i'jaz Bayani.}

Golongan ini melihat, bahwa aspek yang terang, jelas dan transparan bagi aspek kemukjizatan alQur'an adalah aspek bahasa yang dimilikinya, 
sebagaimana dari kalangan mereka juga ada yang membatasi aspek kemukjizatan al-Qur'an hanya pada aspek ini saja. Adapun kandungan al-Qur'an yang menunjukkan bahwasanya ia merupakan kalamullah, seperti: pemberitaannya, hukumnya, ilmu pengetahuannya dan sebagainya adalah tidakdapat dikategorikan sebagai bagian dari aspek kemukjizatan al-Qur'an. Diantara ulama yang berpendapat semacam ini adalah Syaikh Amin Al Khuli, seorang guru besar bidang ilmu bahasa di beberapa Universitas di Mesir. Argumentasi al-Khuli (1993) adalah sebagai berikut.

Pertama, pemahaman yang akurat dan pas terhadap sebuah kata mengharuskan kita untuk memahaminya sebatas pemakaiannya ketika kata itu diturunkan. Hal ini melarang kita untuk terlalu luas dalam memahami kata tersebut dengan memberikannnya makna-makna yang tidak dikenal saat al-Qur'an diturunkan.

Kedua, hendaknya kita memahami 'Ibarat (ungkapan-ungkapan) al-Qur'an sebagaimana yang dipahami oleh orang Arab yang masih orisinil dan belum terkontaminasi dengan kebudayaan dan peradaban lain, dan tidak melebihi dalam memahaminya sejauh ilmu pengetahuan yang mereka miliki dan kuasai. Sebab, perkataan yang baligh (fasih) adalah yang memperhatikan kesesuaian dengan kondisi.

Ketiga, sesungguhnya al-Qur'an diturunkan dengan berorientasikan agamis ideologis, bukan scientis (ilmiah).

\section{Golongan kedua, penggagas i'jaz 'ilmi.}

Golongan ini tidak melihat aspek kemukjizatan al-Qur'an hanya terbatas pada aspek bahasa yang dimilikinya, melainkan terdapat banyak aspek lain, selain aspek bahasa yang dapat dijadikan sebagai bagian dari aspek kemukjizatan alQur'an.

Diantara sekian banyak aspek kemukjizatan yang dimiliki al-Qur'an, sesungguhnya aspek ilmu pengetahuan merupakan aspek yang paling dominan dalam pembahasan para ulama, cendekiawan dan penulis abad keempat belas. Diantara mereka terdapat sosok Muhammad Ahmad Ghamrawi, seorang guru besar bidang ilmu kedokteran dan farmasi di Universitas $\mathrm{Al}$ Azhar Mesir, yang menulis dalam bukunya, "AlQur'an merupakan bukti kebenaran Tuhan atas hamba-Nya, dan hendaknya pengetahuan seputar kemukjizatannya tidak terbatas pada aspek bahasanya saja. Sebab, umat manusia secara keseluruhan menjadi bagian dari yang diminta untuk mengimaninya.
Secara kuantitas, sesungguhnya bangsa non Arab jauh lebih banyak dibandingkan dengan bangsa Arab. Atas dasar itu, hendaknya kemukjizatan alQur'an dapat dipahami oleh setiap umat manusia. Realitas semacam ini mengharuskan aspek kemukjizatan al-Qur'an tidak hanya terbatas pada aspek bahasa dan pemberitaannya saja. Sesungguhnya pembahasan seputar kemukjizatan al-Qur'an masih berada di awal perjalanannya, walaupun telah banyak buku yang menulis hal itu, dan aku hanya berkehendak untuk menulisnya dari sisi ilmu pengetahuan yang dikandungnya. Kalau kita memahami sisi ilmu pengetahuan dalam arti yang luas, sesungguhnya ia mencakup segenap aspek selain aspek bahasa, seperti aspek psikologi, hukum, sejarah dan penciptaan alam semesta. Aspekaspek inilah yang hendaknya lebih dikaji lagi oleh kaum muslimin, kemudian menghadirkannya kepada umat manusia pada abad sekarang ini". (Al-Ghamrawi, 1991:211).

Demikian pemaparan singkat sejarah perjalanan pembahasan seputar aspek kemukjizatan alQur'an, dari semenjak masa lampau hingga masa kini. Sebuah pemaparan yang dapat menggambarkan kepada kita perbedaan di kalangan ulama dalam merumuskan aspek kemukjizatan al-Qur'an. Pada pembahasan selanjutnya, penulis berupaya untuk memformulasikan sebuah pendapat yang dalam hemat penulis dapat menjembatani dan mengharmonisasikan perbedaan pendapat diatas.

\section{Antara Mu'jizat atau Bukti Pembenar}

Tidak dapat terelakkan bagi setiap orang yang membahas aspek kemukjizatan al-Qur'an untuk terlebih dahulu menerangkan dua hakekat penting dan merinci keduanya secara jelas serta membedakan di antara sisi-sisi kesamaan yang dimiliki oleh keduanya, agar tidak terjadi kesamaran dan kerancuan dalam memahami keduanya.

Pertama, kemukjizatan al-Qur'an sebagaimana ditilik dari sisi lafazh (kata) dan sejarahnya, merupakan bukti yang dimiliki oleh Nabi Muhammad saw atas kebenaran dakwah kenabian yang diserunya, dan bahwasannya beliau merupakan seorang rasul yang diwahyukan kepadanya al-Qur'an. Pemahaman beliau seputar aspek kemukjizatan al-Qur'an adalah sama sebagaimana yang dipahami oleh kalangan bangsa arab saat itu. Dan, tantangan yang terkandung dalam ayat-ayat tantangan adalah tantangan untuk mendatangkan semisal aspek bahasa yang dimilikinya, bukan aspekaspek lain selainnya, sebab al-Qur'an tidak 
pernah menantang mereka untuk mendatangkan semisal pemberitaan ghaibnya, atau untuk mendatangkan ilmu pengetahuan yang tidak pernah diketahui oleh orang-orang yang diajak bicara dari kalangan bangsa Arab saat al-Qur'an diturunkan, tidak pula dengan aspek-aspek lain yang tidak memiliki keterkaitan dengan aspek bahasanya.

Kedua, sesungguhnya penegasan tentang bukti kenabian, pembenaran tentang argumentasi wahyu, dan bahwasanya al-Qur'an diturunkan dari sisi Allah swt sebagaimana kitab suci-kitab suci sebelumnya, seperti: Taurat, Injil dan Zabur, kesemuanya ini tidak berimplikasi kepada kemukjizatan al-Qur'an. Bukankah selama ini tidak ada seorang pun yang mengatakan bahwasanya Taurat, Injil dan Zabur merupakan sekumpulan kitab suci yang memiliki kandungan mu'jizat sebagaimana yang dimiliki oleh alQur'an, hanya dikarenakan kitab suci-kitab suci tersebut diturunkan dari sisi Allah swt, atau dikarenakan di dalamnya terkandung pemberitaan ghaib?!

Al-Qur'an yang memiliki kandungan mu'jizat dapat dijadikan sebagai bukti yang bersifat absolut akan kebenaran kenabian. Kebenaran kenabian tidaklah dapat dijadikan sebagai argumentasi atas kemukjizatan al-Qur'an. Sesungguhnya pencampur-adukan dua hakekat tersebut, dan pengenyampingan perbedaan antara keduanya, baik secara praktek maupun teori dalam kajian al-Qur'an, telah banyak menimbulkan kerancuan, baik dalam kajian ulama klasik maupun ulama kontemporer (Bin Malik, 2000:24-26).

\section{Argumentasi Aspek Bahasa sebagai Bukti Kemu'jizatan al-Qur'an}

Dalam sejarah, bangsa Arab sangat terkenal dengan kemampuan bahasa mereka yang sangat tinggi. Semakin tinggi kemampuan mereka dalam mengetahui dan menguasai aspek bahasa, semakin terbuka pula tabir kandungan kemukjizatan al-Qur'an, sehingga merekapun tunduk dan mengakui akan kehebatan kandungan bahasa yang dimiliki al-Qur'an.

Fenomena diatas berlaku sebaliknya bagi mereka yang merasa hebat dan terpedaya dengan kemampuan dirinya, seperti sosok Musailamah al-Kadzdzab yang mengklaim sebagai nabi sepeninggalnya Rasulullah saw dan berusaha untuk meniru dan menantang al-Qur'an, akan tetapi klaim tersebut berakhir dengan kegagalan, bahkan mendapat cemooh dan hinaan dari masyarakat Arab. Sebagai contoh, penulis nukilkan di bawah ini perkataan Musailamah Al
Kadzdzab yang dianggapnya dapat menandingi sebagian ayat-ayat al-Qur'an :

$$
\text { وأسفلك ضفو بنت الطين ضفدعين، نقي ما تتقين، أعلاك بوْ الماء }
$$

Artinya: "Hai katak anak dari dua katak, bersihkanlah apa-apa yang akan engkau bersihkan, bahagian atas engkau di air dan bahagian bawah engkau di tanah".

Seorang sastrawan Arab bernama al-Jahiz telah memberikan penilaiannya atas gubahan Musailamah ini dalam bukunya yang berjudul " $a l$ Hayawan" sebagai berikut. "Saya tidak mengerti apakah gerangan yang menggerakkan jiwa Musailamah menyebut katak dan sebagainya itu. Alangkah kotornya gubahan yang dikatakannya sebagai ayat al-Qur'an yang turun kepadanya sebagai wahyu" (Departemen Agama RI, 107).

Sejarah pun mencatat, bahwa semenjak diturunkan ayat yang berisikan tantangan untuk mendatangkan semisal al-Qur'an sampai sekarang dan bahkan tantangan ini masih berlanjut sampai hari kiamat, belum ada dan tidak akan ada, baik dari kalangan manusia maupun jin yang mampu dan berhasil mendatangkan semisal al-Qur'an, ditilik dari aspek bahasa yang dimilikinya.

Ketidakmampuan mereka yang notabene merupakan para pakar dan begawan bahasa untuk mendatangkan semisal al-Qur'an, dan upaya mereka untuk menutupi ketidakmampuan tersebut dengan lebih memilih berperang di medan peperangan, merupakan sebuah bukti pembenar atas kandungan mukjizat yang dimiliki al-Qur'an.

Sangat tidak logis dan realistis kalau ada yang berpendapat, bahwasanya mendatangkan semisal al-Qur'an adalah sesuatu yang memungkinkan akan tetapi tidak terdapat urgenitas (kebutuhan) untuk mendatangkan semisalnya. Sejarah telah mencatat bahwa banyak faktor yang semestinya mendorong kaum musyrikin untuk menantang dan mendatangkan semisal al-Qur'an. Bukankah mereka selalu mengingkari sosok Rasulullah saw dan dakwah kenabian yang dibawanya?, sebagaimana berbagai cara untuk membungkam dakwah beliau pun kerap mereka lakukan. Mereka menawarkan harta dan jabatan kepada Nabi, mereka memboikot beliau dan segenap pengikutnya, dan mereka pun menuduh beliau sebagai seorang yang gila dan terkena sihir. Bahkan, mereka mengadakan konspirasi sesama mereka untuk menahan, membunuh dan mengusir beliau. 
Semua yang mereka lakukan, sama sekali tidak mampu untuk membungkam seruan dakwah beliau, padahal mereka telah diberi tawaran untuk memilih sebuah cara yang jauh lebih gampang dan praktis -kalau saja mereka mampuuntuk membungkamnya, yakni dengan mendatangkan semisal apa yang beliau datangkan kepada mereka, yakni al-Qur'an. Akan tetapi, tawaran ini tidak mereka lirik dan lakukan. Keengganan mereka ini tidak lain sebagai sinyal kuat akan ketidak mampuan mereka (Al-Qaththan, 1990:72-74). Padahal, permisalan al-Qur'an yang diminta dari mereka juga dengan menggunakan bahasa yang selama ini mereka kenal dan pergunakan dalam keseharian mereka.

Sejarah juga telah mencatat betapa besar pengaruh yang dapat ditimbul oleh al-Qur'an secara spontanitas, baik dalam diri kaum musyrikin lebih-lebih lagi dalam diri kaum umat Islam. Kisah Umar bin Khattab saat memeluk agama Islam, ketika amarahnya telah memuncak, kemudian ia membaca beberapa ayat dalam surah Thaha, lalu ia pun tidak dapat menyembunyikan rasa kekagumannya atas keindahan redaksi yang dimiliki al-Qur'an, hingga kemarahannya pun secara spontan berubah padam, sebagaimana air memadamkan panasnya api, hidayah Islam pun masuk ke dalam dirinya dari arah yang tidak disangka-sangka.

Apa yang terjadi dalam diri Umar bin Khattab, sesungguhnya sama dengan apa yang terjadi atas diri al-Walid bin al-Mughirah. Pengetahuan alWalid yang luas tentang seluk-beluk bahasa Arab, mengantarkannya setelah mendengarkan lantunan al-Qur'an yang dibaca Rasulullah saw untuk mengeluarkan sebuah pernyataannya yang populer, yaitu:

$$
\text { وإن ألله إن لقولهه لحهلاوة وإن عليه لطلاوة وإن أسفله لمغدق ما يقول هـا بشر }
$$

Artinya: "Demi Tuhan, sungguh indah dan tersusun rapi perkataan (al-Qur'an) yang dilantunkan Muhammad. Kalau diibaratkan seperti pohon maka tanah dibawahnya sangat subur, sebagaimana diatasnya produktif menghasilkan buah. Tidak mungkin perkataan seperti ini diciptakan oleh seorang manusia".

Demikian, saat manusia berupaya untuk lebih memperhatikan aspek bahasa yang dimilik oleh al-Qur'an, ia akan mendapatkan rahasia-rahasia yang terkandung dalam kemukjizatannya. Begitu banyaknya fenomena menakjubkan ini, yang muncul sebagai akibat dari keindahan bahasa alQur'an, sehingga para ulama mengatakan,
"Sesungguhnya bahasa al-Qur'an adalah bahasa arab yang tidak asing dan telah banyak dikenal oleh bangsa Arab, sebagaimana pada saat yang bersamaan bahasa al-Qur'an juga bukanlah merupakan bahasa mereka".

Ia merupakan bahasa bangsa Arab yang telah dikenal oleh mereka, karena terdapat banyak kesamaan yang dimiliki oleh keduanya. Lafazh yang terdapat di dalam bahasa al-Qur'an tidak keluar dari lafazh yang terdapat dalam bahasa Arab, sebagaimana dari sisi tarkib (susunan kata) pun demikian. Atas dasar itu, tidak ditemukan seseorang pun dari bangsa Arab yang menolak arabisme (sifat kearaban) yang melekat pada lafazh-lafazh yang terdapat di dalam al-Qur'an atau mengkritiki susunan kalimatnya.

Kalaupun bahasa al-Qur'an adalah berbeda dengan bahasa arab, hal ini dikarenakan beberapa faktor di bawah ini.

Pertama, al-Mufradat (kosa kata) yang dimiliki bahasa al-Qur'an walaupun ia termasuk bagian dari al-Mufradat yang dimiliki bahasa arab, akan tetapi di antara keduanya terdapat perbedaan dalam hal makna yang dimaksud. Karena, bisa jadi makna yang terkandung dalam bahasa alQur'an tidak demikian dalam bahasa Arab atau bahkan tidak pernah ditunjukkan sebelumnya oleh bahasa Arab. Hal ini sangat dimungkinkan karena bahasa al-Qur'an pada hakekatnya merupakan intisari dari bahasa Arab tersebut.

Kedua, apabila bahasa arab merupakan media komunikasi antara bangsa Arab atau mereka yang mempelajari bahasa Arab yang kesemuanya merupakan bagian dari sesama manusia, maka bahasa al-Qur'an merupakan media komunikasi antara manusia dengan Dzat pencipta alam semesta ini. Atas dasar itu dan pada sisi ini terdapat perbedaan yang mendasar antara bahasa Arab dengan bahasa al-Qur'an, baik ditilik dari sisi usluub, tarkiib dan pemilihan lafazhlafazhnya. Fakta telah membuktikan bahwa segenap makhluk tidak memiliki kemampuan untuk meniru atau mendatangkan semisal alQur'an, meski hanya satu surah terpendek darinya.

Atas dasar itu, sangat tidak adil bagi bahasa alQur'an dengan kekhususan di atas untuk disamakan dan disejajarkan dengan bahasa arab yang memiliki keterbatasan, baik dari sisi makna, usluub maupun tarkiib. Sebab, keterbatasan yang dimiliki oleh bahasa Arab ini sangat dimungkinkan untuk ditiru atau didatangkan yang lebih baik darinya, baik dari sisi bayan (kejelasan) atau balaghah-nya. 
Ketiga, tarkiib yang dimiliki bahasa al-Qur'an walaupun sejalan dengan tarkiib yang dimiliki oleh bahasa Arab, akan tetapi bahasa al-Qur'an sangat berbeda dengan bahasa Arab baik dari sisi bayan, balaghah maupun dari sisi badi' (retorika) yang dimilikinya. Pengaruh yang ditimbulkan alQur'an, yang telah mampu memberikan penerangan bagi alam jagat raya ini dan pencerahan atas diri manusia, tidak mungkin fenomena ini ditimbulkan melainkan oleh sebuah kitab yang ayat-ayatnya disusun dengan rapi, serta dijelaskan secara terperinci dan diturunkan dari Allah, Tuhan semesta alam.

Atas dasar ini, maka tarkiib yang dimiliki oleh bahasa al-Qur'an sangat berbeda dengan tarkiib yang dimiliki oleh bahasa Arab, baik dari aspek makna, cara penyampaian maupun visi dan misinya, disamping juga kandungan dari redaksi al-Qur'an yang memuat hikmah dan rahasia Ilahiyyah yang tidak terdapat di dalam bahasa Arab.

Keempat, usluub atau gaya bahasa yang dipakai oleh bahasa al-Qur'an dalam menggambarkan makna yang terkandung di dalamnya merupakan sebuah usluub tersendiri yang tidak pernah dikenal oleh bangsa Arab sebelum al-Qur'an diturunkan, bahkan sampai sekarang dan akan berkelanjutan sampai akhir zaman.

Usluub yang dimiliki bahasa al-Qur'an benarbenar berbeda dengan usluub yang sudah dikenal oleh bangsa Arab, baik yang berupa sajak, prosa, kisah, perumpamaan juga korespondensi. Ia sangat berbeda dengan apa yang telah dimiliki dan dikenal oleh bangsa Arab dari macam-macam bentuk tulisan dan perkataan. Atas dasar itu, tidak benar kalau sebuah usluub yang memiliki keistimewaan dan kekhususan tersebut untuk disifati dan dinamakan melainkan dengan uslub al-Qur'an itu sendiri.

Apabila bahasa al-Qur'an yang sangat kental dengan aroma yang bersifat ilahiyah (ketuhanan) karena kekhususan dan keistimewaan yang dimilikinya tersebut, maka sangat objektif bila dikatakan bahwa, "bahasa al-Qur'an adalah lain dan berbeda dengan bahasa arab?". Sebagaimana al-tasyabuh al-zhahir (kemiripan yang tampak) antara keduanya dalam bentuk, tidaklah berarti menafikan perbedaan antara keduanya yang lebih bersifat substansif dan hakiki, seperti halnya kemiripan antara sebuah patung dengan gambar seseorang manusia, juga tidaklah berarti bahwa antara keduanya adalah sama, sebagaimana sangatlah mustahil bagi sebuah patung untuk dikatakan bahwasannya ia adalah seseorang manusia (Abdur Rahim, 1980, 8-10).

\section{Problematika Seputar Aspek Bahasa}

Dikatakan, bahwasanya konsep i'jaz bayani mengandung dua problematika mendasar yang keduannya kerap dihadapi baik oleh generasi dahulu, maupun genarasi sekarang.

Pertama, bagaimana konsep ini dapat dimengerti, pada saat yang sama naluri berbahasa Arab sudah menurun dan adanya perbedaan yang sangat signifikan antara generasi sekarang dengan generasi sewaktu al-Qur'an diturunkan, dari sisi kepiawaian dalam berbahasa?

Kedua, bagaimana komunitas non Arab dapat memahami dan mempercayai kemukjizatan alQur'an berdasarkan konsep ini, bukankah ajaran Islam bersifat universal dan diperuntukkan bagi segenap umat manusia?

Mereka yang kerap memunculkan dua problematika di atas, menghendaki adanya aspek-aspek lain bagi kemukjizatan al-Qur'an, seperti: pemberitaan, hukum, dan ilmu pengetahuan, dan lain-lain. Penulis tidak mengingkari bahwasanya kandungan al-Qur'an merupakan sebuah media dakwah yang sangat penting, akan tetapi pada sisi yang lain, penulis tidak setuju kalau kandungannya mengandung tantangan dan dijadikan sebagai sebuah tolak ukur bagi kemukjizatannya.

Berkaitan dengan problematika pertama, bahwasanya kemukjizatan al-Qur'an apabila telah diakui keberadaannya oleh para generasi awal, yang secara kemampuan berbahasanya sangat baik, maka selayaknya generasi-generasi selanjutnya yang secara kemampuan berbahasa jauh dibawah mereka untuk lebih mengakuinya, demikian sebagaimana yang telah banyak dijawab oleh para ulama klasik.

Hakekat kemukjizatan al-Qur'an tetap berada pada setiap saat, walaupun terdapat beberapa generasi yang tidak mampu untuk menangkap dan memahami aspek kemukjizatannya. Bahkan, tidak berlebihan kalau penulis katakan, bahwasanya generasi kita sekarang lebih mampu untuk menangkap dan memahami beberapa sisi dari konsep i'jaz bayani. Banyaknya kajian tentang kritik kesusastraan, baik dalam bahasa arab maupun bahasa-bahasa lainnya, dapat membuktikan akan kebenaran pernyataan penulis atau paling tidak fenomena tersebut mampu untuk menggantikan naluri berbahasa yang telah mengikis dan menghilang sebagaimana yang dimiliki oleh para generasi awal. 
Adapun yang berkaitan dengan problematika kedua, penulis tidak tahu, apakah kita masih menunggu agar al-Qur'an diturunkan dengan segenap bahasa yang ada di bumi, sehingga dapat memenuhi kebutuhan segenap komunitas non Arab? Menurut penulis, tidak mungkin dan tidak akan terjadi sampai hari kiamat.

Bahasa yang dipakai oleh al-Qur'an, sejatinya merupakan sebuah bahasa terbaik yang Allah swt pilihkan untuk sebuah kitab suci penutup yang membenarkan dan meluruskan kandungan kitab suci-kitab suci sebelumnya. Atas dasar itu, tidak ada alasan bagi komunitas non Arab -khususnyauntuk tidak mengkaji dan memahami kandungannya. Dalam konteks ini, Allah swt berfirman, "Dan sungguh Kami telah mempermudah al-Qur'an untuk menjadi pelajaran, maka adakah yang akan mengambil pelajaran"(QS. Al-Qamar [54]:17).

Problematika non Arab dengan ajaran Islam, hakekat keimanan, kebenaran al-Qur'an dan konsep wahyu sesungguhnya sangat mudah untuk dicarikan solusinya. Kita tidak harus menghadirkan konsep i'jaz bayani bahasa yang dimiliki oleh al-Qur'an, melainkan kita berbicara dengan mereka dengan menggunakan cara lain, yakni, dengan menghadirkan kepada mereka bukti-bukti yang sangat banyak dari kandungan al-Qur'an yang dapat membenarkan bahwasanya ia diturunkan dari sisi Allah swt, seperti: aspek ilmu pengetahuan, aspek pemberitaan ghaib, aspek hukum, dan sebagainya (Abdul Fatah, 2000:118).

Sebagai satu contoh kongkrit, misalnya al-Qur'an telah menginformasikan kepada kita bahwasanya janin dalam perut ibunya diliputi oleh tiga kegelapan. "Dia menjadikan kamu dalam perut ibumu kejadian demi kejadian dalam tiga kegelapan". (QS. Al-Zumar [39]:6).

Para ilmuan kontemporer telah berhasil mengidentifikasi tiga kegelapan yang meliputi si janin sebagaimana yang diinformasikan oleh alQur'an diatas. Pertanyaannya adalah siapa yang telah mengajari seorang buta aksara semacam Muhammad saw, pada lima belas abad yang lalu akan adanya tiga kegelapan yang meliputi sang janin? bukankah dia tidak pernah mempelajari ilmu kedokteran, belum pula memiliki alat secanggih yang dimiliki oleh para ilmuwan kontemporer, semacam USG (ultrasonografi) yang dapat menggambarkan kondisi janin dalam rahim ibunya?!

Menurut penulis, sesungguhnya hakekat ilmiah yang telah disebutkan oleh al-Qur'an pada lima belas abad yang lalu, dan telah dibenarkan oleh para ilmuan kontemporer berdasarkan riset dan kajian mereka, merupakan sebuah bukti kuat bahwasanya al-Qur'an merupakan kalamullah, Muhammad saw merupakan Rasulullah, dan Islam merupakan agama yang benar, maka cermatilah, dan masuklah ke dalam agama Islam!

Hal ini tentunya berbeda, ketika penulis mengatakan, bahwasannya ayat $\mathrm{di}$ atas merupakan bagian dari i'jaz bayani dalam alQur'an. Karena, ketika penulis mengatakan bahwasannya ayat tersebut bagian dari mu'jizat al-Qur'an, berarti: “Kami menantang segenap jin dan manusia untuk mendatangkan sebuah ilmu pengetahuan semacam ilmu pengetahuan yang terkandung dalam ayat tersebut". Dengan kata lain: "Datangkan dan perlihatkan kepada Kami tiga kegelapan yang meliputi janin dalam rahim ibunya sebagaimana yang diinformasikan oleh alQur'an!".

Ketika kami menantang mereka dengan semacam tantangan di atas, pertanyaannya adalah: apakah mereka sanggup untuk mendatangkan dan memperlihatkan permintaan Kami atau tidak mampu untuk mendatangkan dan memperlihatkannya? Sesungguhnya mereka akan sanggup mendatangkan dan memperlihatkannya.

Mereka akan mengatakan, berdasarkan riset dan kajian yang telah penulis lakukan, penulis telah sanggup menemukan tiga kegelapan tersebut, bahkan lebih dari itu penulis telah berhasil mengidentifikasi dan merinci ketiga kegelapan yang meliputi janin dalam rahim ibunya. Professor Keith L Moore, seorang guru besar bidang ilmu anatomi dan embrio di Universitas Toronto Kanada, berkata bahwasanya ketiga kegelapan yang disebutkan dalam Al-Quran itu adalah pertama, dinding depan perut ibu; kedua, dinding rahim; ketiga, selaput yang melindungi janin (Membran Amnion), yang disebut dengan The Amnionic-Chronic Membrance (www.kafegaul.com).

Keberhasilan para embriolog dalam mengidentifikasi dan merinci ketiga kegelapan, dapat dipahami bahwaa mereka telah mampu untuk mendatangkan tantangan al-Qur'an, apabila ayat diatas dipahami sebagai sebuah i'jaz 'ilmi. Hal ini juga berarti, bahwasanya kemukjizatan al-Qur'an telah terbantahkan dan sudah tidak berlaku lagi dengan keberhasilan para embriolog di atas.

Atas dasar itulah, dan agar tidak terjebak pada kesimpulan di atas, hendaknya kita membedakan antara menjadikan isyarat-isyarat ilmiah yang terdapat dalam al-Qur'an sebagai i'jaz 'ilmi, atau menjadikannya sebatas bukti penguat 
bahwasanya al-Qur'an benar bersumber dari Allah swt (Abdul Fatah, 2000:115).

\section{Penutup}

Terdapat perbedaan di antara para ulama dalam merumuskan aspek kemukjizatan al-Qur'an, sebuah perbedaan yang baru muncul dan lahir pasca generasi awal. Sejalan dengan perjalanan waktu, perbedaan ini makin beragam dan bervariasi. Aspek bahasa merupakan satusatunya aspek yang menjadikan al-Qur'an sebagai kitab suci yang memiliki kandungan kemukjizatan. Adapun kandungan dalam alQur'an seperti tentang pemberitaan ghaib, kelengkapan hukum, dan keajaiban ciptaan Tuhan yang tersebar di alam raya ini, kesemua ini tidak ada keterkaitannya dengan tantangan yang berimplikasi kepada sebuah kemukjizatan, melainkan keberadaan kesemuanya dalam kandungan al-Qur'an sebatas bagian dari bukti penguat yang membenarkan bahwasannya alQur'an diturunkan dari sisi Allah swt (Zarzur, 1984:230).
Bahasa al-Qur'an secara lisan memiliki kesamaan dengan bahasa arab, akan tetapi tidak demikian dalam hal sifat dan karakter yang dimiliki oleh keduanya. Sebab, bahasa arab merupakan produk manusia yang memiliki sisi positif dan negatif yang tentunya tidak demikian dengan bahasa alQur'an yang merupakan produk Tuhan. Fakta iniyang melahirkan dan memperkuat aspek kemukjizatan yang dimiliki oleh al-Qur'an.

Turunnya naluri berbahasa Arab pada generasi saat ini, tidak bisa dijadikan pembenar untuk melahirkan aspek lain -selain aspek bahasa- bagi kemukjizatan al-Qur'an sebagaimana universalitas ajaran Islam yang tidak mengharuskan dan membatasi dakwah terhadap non Arab hanya dengan aspek bahasa al-Qur'an, karena masih banyak aspek-aspek kandungan alQur'an lainnya, seperti aspek pemberitaan, hukum, sains, dan sebagainya yang dapat dijadikan sebagai media untuk mendakwahkan kebenaran al-Qur'an.

\section{DAFTAR PUSTAKA}

Abdul Fattah, Shalah. 2000. I'jaz al-Qur'an al-Bayani wa Dalail Mashdarihi al-Rabbani. Damaskus: Dar 'Ammar.

Abdur Rahim, Abdul Jalil. 1980. Lughah al-Qur'an. Kairo: Al-Risalah Al-Haditshah.

Al-Baqilani, Abu Bakar. 1978. I'jaz al-Qur'an. Kairo: Al-Musthafa Al-Babi Al-Halabi.

Al-Ghamrawi, Ahmad. 1991. Al-Islam fii 'Ashr al-'Ilm. Bairut: Dar Al-Insan.

Al-Khuli, Amin. 1993. Al-Tafsir, Manhajuhu al-Yaum, Ma'aalim Hayatihi. Kairo: Jama'ah Al Kuttab.

Al-Qaththan, Manna'. 1990. Mabahis fii 'Ulum al-Qur'an Bairut: Wahbah.

Al-Qurthubi, Abu Abdullah. 1993. Al-Jami' li Ahkaam al-Qur'an. Bairut: Dar al-Fikr.

Bin Nabi, Malik. 2000. Al-Zhahirah Al Qur'âniyyah. Bairut: Dar al-Fikr.

Departemen Agama RI. Tanpa tahun. Al-Qur'an dan Terjemahannya. Jakarta: Gema Risalah Press.

Zarzur, Adnan. 1984. Ulum al-Qur'an Madkhal Ila Tafsir al-Qur'an wa Bayan I'jazihi. Kairo: AlMaktab Al-Islami. 